\title{
Cattle tissues as a source of cadmium for consumers
}

\author{
Jiří Ruprich ${ }^{1,2}$, Jiří Drápal ${ }^{2,3}$, Irena Řehůřková1, Kamil Št’astný4 ${ }^{4}$, Martina Kalivodová ${ }^{1}$ \\ ${ }^{1}$ National Institute of Public Health, Centre for Health, Nutrition and Food, Brno, Czech Republic \\ ${ }^{2}$ University of Veterinary and Pharmaceutical Sciences Brno, Faculty of Veterinary Hygiene and Ecology, \\ Brno, Czech Republic \\ ${ }^{3}$ Central State Veterinary Administration of the State Veterinary Administration, Prague, Czech Republic \\ ${ }^{4}$ Veterinary Research Institute, Brno, Czech Republic \\ Received February 26, 2015 \\ Accepted May 13, 2015
}

\begin{abstract}
The aim of this study was to re-evaluate the analytical results and time trends of the content of cadmium in muscle, liver, and kidney samples of young bovine animals and cows slaughtered in the Czech Republic during the years 1993-2010, and to estimate the total dietary exposure for the entire population aged 4-90 years and specifically, for children at the age of four to six years. Analyses showed that the arithmetic means of cadmium concentration in cow kidney and liver are higher than in young bovine $(P<0.0001)$, but not in muscle $(P=0.227)$. The mean cadmium concentration in cow kidney $\left(0.595 \mathrm{mg} \cdot \mathrm{kg}^{-1}\right)$ was twice as high as in young bovine kidney $(0.285$ $\left.\mathrm{mg} \cdot \mathrm{kg}^{-1}\right)$ for the entire studied period. The mean concentration of cadmium in cow liver $(0.113$ $\left.\mathrm{mg} \cdot \mathrm{kg}^{-1}\right)$ was higher compared to young bovine liver $\left(0.078 \mathrm{mg} \cdot \mathrm{kg}^{-1}\right)$. The mean concentration of cadmium in cow muscle $\left(0.008 \mathrm{mg} \cdot \mathrm{kg}^{-1}\right)$ was comparable with young bovine muscle $(0.006$ $\left.\mathrm{mg} \cdot \mathrm{kg}^{-1}\right)$. The evaluation of time trends showed increasing concentrations of cadmium for cow (increasing slaughtering age) and young bovine kidney and decreasing concentrations for cow and young bovine muscle, but no significant change for liver. The estimated $\mathrm{Cd}$ burden of the entire population is worthy of attention $\left(10 \%\right.$ were over the tolerable dose of $2.5 \mu \mathrm{g} \cdot \mathrm{kg}^{-1} \mathrm{body}$ weight and week). For more than $50 \%$ of four to six-year-old children the burden exceeded the tolerable weekly intake. The contribution of food belonging to the group of meat and meat products, including cattle tissues, to usual cadmium exposure is only $5 \%$. Nevertheless, the food safety recommendation is not to consume cow kidney as food.
\end{abstract}

Food, kidney, contamination, heavy metals, trend, exposure

Cadmium $(\mathrm{Cd})$ is a toxic metal occurring in the environment from natural sources and also as a consequence of anthropogenic activities related to industry and agriculture. Many legislative control measures have been taken to decrease the contamination of foodstuff in Europe since the 1970s and this regulatory effort continues until the present time when new emerging toxicological data were collected (EFSA 2011). For a non-smoking person who is not occupationally exposed to Cd, foodstuffs represent the source of up to $90 \%$ of his or her total intake of Cd (EFSA 2009). Smokers have $\times 4-5$ higher Cd concentrations in the blood and $\times 2-3$ higher Cd contents in the kidneys (Dallongewille et al. 1998). The absorption of $\mathrm{Cd}$ through the human digestive tract is relatively low (3-5\%). Cadmium accumulated in the kidneys and liver has a very long half-time of excretion from the human body, in the range of 10-30 years (Kjellström and Nordberg 1978; EFSA 2009). Cadmium is primarily toxic for the kidneys. Exposure to $\mathrm{Cd}$ is associated with many other effects such as nephrotoxic, neurotoxic, carcinogenic, genotoxic, and teratogenic effects, the development of osteoporosis or osteomalacia, damage to the endocrine system and reproductive functions (EFSA 2009). It is also classified as a group 1 human carcinogen (IARC 2015). In 2009, EFSA re-evaluated the existing Tolerable Weekly Intake (TWI) of $\mathrm{Cd}$ and set it to $2.5 \mu \mathrm{g} \cdot \mathrm{kg}^{-1}$ body weight (EFSA 2009, 2011). Regulation (EC) No. $1881 / 2006$ establishes the maximum limit (ML) for Cd content in meat (excluding offal) of 
bovine animals, sheep, porcine animals and poultry as follows: $0.050 \mathrm{mg} \cdot \mathrm{kg}^{-1}$ wet weight; for liver: $0.50 \mathrm{mg} \cdot \mathrm{kg}^{-1}$ wet weight; and for kidney: $1.0 \mathrm{mg} \cdot \mathrm{kg}^{-1}$ wet weight.

The aim of this study was to re-evaluate the recent analytical results and time trends of the content of $\mathrm{Cd}$ in muscle, liver and kidney samples of young bovine animals and cows slaughtered in the Czech Republic during the years of 1993-2010, and to estimate consequences for the total dietary exposure of the whole population of consumers and specifically, for younger children.

\section{Materials and Methods}

Sampling of cattle tissues and market food samples

Samples of bovine meat and offal were collected by the Czech State Veterinary Administration (SVA), within the implementation of the national plan for the monitoring of residues and contaminants in accordance with the Council Directive 96/23/EC (1996) and Commission Decision 97/747/EC (1997) in the years 1993-2010. The sampling methodology was previously described by Drápal et al. (2012).

Market food samples representing a common Czech diet were collected in all country regions as part of the national Total Diet Study during the years 2004-2011. The sampling methodology was described by Ruprich (2014).

Analytical methods

Samples of cattle tissues were analysed by SVA laboratories. Homogenized samples of biological material were mineralized in a microwave device (Ethos plus, Milestone) after the addition of concentrated nitric acid and hydrogen peroxide. Determination of cadmium was carried out using graphite furnace atomic absorption spectrometry with Zeeman correction (GF-AAS) (Varian 1985, 1988), and in some cases by using inductively coupled plasma mass spectrometry (ICP-MS) (Varian 2004). The levels of quantification (LOQ) were 0.01 $\mathrm{mg} \cdot \mathrm{kg}^{-1}$ for liver and kidney, and $0.005 \mathrm{mg} \cdot \mathrm{kg}^{-1}$ for muscle. The results were provided in the Standard sample description for food and feed format developed by EFSA (2010).

Analyses of market food at the laboratories of the National Institute of Public Health used the microwave wet digestion in a closed system (Ethos plus, Milestone) using nitric acid and hydrogen peroxide. Then, evaporation (Start D, Milestone) was used too, for mineralization of food samples and GF-AAS with Zeeman correction for determination of Cd (Perkin-Elmer 1991, 1999). The range of LOQs was $0.0001-0.002 \mathrm{mg} \cdot \mathrm{kg}^{-1}$ of various food samples. All methods employed were accredited according to the European Standard EN ISO/IEC 17025.

\section{Statistical analyses}

Statistical evaluation of trends was performed using the linear regression analysis. $T$-test for independent samples was used to analyse the difference between observed concentrations of Cd for both cattle categories. A probability lower than $0.05(P<0.05)$ was considered as significant. Regression analyses and $t$-test were performed using the STATISTICA 12 software (StatSoft 2013).

\section{Exposure assessment}

Exposure assessment was done by the Monte Carlo Risk Assessment modelling software (MCRA), version 8.0 (RIVM, NL). Food consumption datasets, used from the Individual Food Consumption national study SISP04 (Ruprich et al. 2006), were reorganized into 20 Level 1 food groups, according to the FoodEx1 EFSA hierarchic classification system. Food concentration data (3520 analytical results) for Cd came from the national Total Diet Study (Ruprich 2014). The data represent dietary sources from analyses performed during the time period of 2004-2011. For evaluation of total exposure doses of Cd the following MCRA calculation parameters were used: Logistic-Normal Normal (LNN) exposure model, uncertainty analysis based on 10000 MC simulations, 100 resampling cycles, replacement of values < LOQ by $50 \%$ of LOQ (middle bound).

\section{Results}

The analytical results from SVA (9729 individual samples) were organized according to tissue, year of collection, and category of slaughtered animals. The means and range of cadmium content in bovine tissues $\left(\mathrm{mg} \cdot \mathrm{kg}^{-1}\right.$ wet weight) in the Czech Republic during the years 1993-2010 are summarized in Table 1. Statistical testing ( $t$-test) showed significant differences between the observed mean concentrations for both studied cattle categories for samples of kidney $(P=0.000004)$ and liver $(P<0.000001)$, but not for muscle $(P=0.2265)$. Evaluation of trends showed increasing concentrations of $\mathrm{Cd}$ in cow and young bovine kidney. The result of the analysis is presented in Fig. 1. The model for cow 
Table 1. The cadmium content in bovine tissues in the Czech Republic in the years 1993-2010 (mg $\mathrm{kg}^{-1}$ wet weight) (for calculation of mean and range values $<$ LOQ were replaced by $50 \%$ of LOQ value $=$ middle bound values)

\begin{tabular}{|c|c|c|c|c|c|c|c|c|c|}
\hline \multirow{2}{*}{ Tissue } & \multirow{2}{*}{ Year } & \multicolumn{4}{|c|}{$\begin{array}{r}\text { Cows }(>2 \text { years }) \\
\mathrm{mg} \cdot \mathrm{kg}^{-1} \text { wet weight }\end{array}$} & \multicolumn{4}{|c|}{$\begin{array}{c}\text { Young bovine }(>6 \text { months }<2 \text { years }) \\
\mathrm{mg} \cdot \mathrm{kg}^{-1} \text { wet weight }\end{array}$} \\
\hline & & $\mathrm{n}$ & Mean & $\begin{array}{l}\text { Range } \\
(\mathrm{min})\end{array}$ & $\begin{array}{l}\text { Range } \\
(\max )\end{array}$ & $\mathrm{n}$ & Mean & $\begin{array}{l}\text { Range } \\
(\mathrm{min})\end{array}$ & $\begin{array}{l}\text { Range } \\
(\max )\end{array}$ \\
\hline \multirow{10}{*}{ Muscle } & 1993-1994 & 367 & 0.008 & 0.003 & 0.070 & 606 & 0.008 & 0.003 & 0.102 \\
\hline & 1995-1996 & 222 & 0.008 & 0.003 & 0.275 & 280 & 0.008 & 0.003 & 0.392 \\
\hline & 1997-1998 & 152 & 0.007 & 0.003 & 0.050 & 143 & 0.008 & 0.003 & 0.060 \\
\hline & $1999-2000$ & 186 & 0.008 & 0.003 & 0.080 & 167 & 0.008 & 0.003 & 0.394 \\
\hline & $2001-2002$ & 228 & 0.007 & 0.003 & 0.039 & 235 & 0.006 & 0.003 & 0.028 \\
\hline & 2003-2004 & 180 & 0.010 & 0.003 & 0.640 & 197 & 0.005 & 0.003 & 0.049 \\
\hline & 2005-2006 & 77 & 0.016 & 0.003 & 0.781 & 74 & 0.004 & 0.003 & 0.021 \\
\hline & $2007-2008$ & 55 & 0.003 & 0.002 & 0.010 & 23 & 0.002 & 0.002 & 0.007 \\
\hline & 2009-2010 & 49 & 0.002 & 0.003 & 0.005 & 31 & 0.002 & 0.003 & 0.003 \\
\hline & Total & 1516 & & 0.003 & 0.781 & 1756 & & 0.003 & 0.394 \\
\hline \multirow{8}{*}{ Liver } & 1993-1994 & 384 & 0.111 & 0.005 & 0.930 & 593 & 0.085 & 0.005 & 2.000 \\
\hline & 1995-1996 & 225 & 0.111 & 0.005 & 0.920 & 275 & 0.071 & 0.005 & 0.690 \\
\hline & 1997-1998 & 138 & 0.109 & 0.005 & 0.420 & 139 & 0.081 & 0.013 & 0.390 \\
\hline & $1999-2000$ & 185 & 0.127 & 0.020 & 3.348 & 159 & 0.079 & 0.020 & 0.420 \\
\hline & 2001-2002 & 229 & 0.099 & 0.020 & 0.504 & 237 & 0.074 & 0.008 & 0.330 \\
\hline & 2003-2004 & 165 & 0.099 & 0.018 & 0.547 & 194 & 0.074 & 0.003 & 0.436 \\
\hline & 2005-2006 & 75 & 0.122 & 0.005 & 0.400 & 75 & 0.079 & 0.015 & 0.280 \\
\hline & $2007-2008$ & 53 & 0.116 & 0.012 & 0.300 & 27 & 0.081 & 0.027 & 0.232 \\
\hline \multirow{12}{*}{ Kidney } & 2009-2010 & 50 & 0.119 & 0.026 & 0.510 & 31 & 0.079 & 0.017 & 0.220 \\
\hline & Total & 1504 & & 0.005 & 3.348 & 1730 & & 0.005 & 2.000 \\
\hline & 1993-1994 & 388 & 0.454 & 0.005 & 2.980 & 593 & 0.264 & 0.005 & 1.559 \\
\hline & 1995-1996 & 215 & 0.471 & 0.005 & 2.400 & 272 & 0.257 & 0.005 & 1.670 \\
\hline & $1997-1998$ & 135 & 0.513 & 0.020 & 1.910 & 137 & 0.306 & 0.055 & 1.340 \\
\hline & $1999-2000$ & 183 & 0.584 & 0.020 & 5.500 & 157 & 0.270 & 0.005 & 1.160 \\
\hline & 2001-2002 & 227 & 0.521 & 0.048 & 2.895 & 235 & 0.271 & 0.020 & 1.760 \\
\hline & 2003-2004 & 169 & 0.557 & 0,087 & 2.895 & 203 & 0.277 & 0.040 & 1.110 \\
\hline & 2005-2006 & 79 & 0.636 & 0.050 & 3.500 & 73 & 0.319 & 0.050 & 1.880 \\
\hline & $2007-2008$ & 52 & 0.816 & 0.199 & 2.020 & 24 & 0.289 & 0.012 & 1.000 \\
\hline & $2009-2010$ & 50 & 0.799 & 0.111 & 2.240 & 31 & 0.308 & 0.042 & 1.200 \\
\hline & Total & 1498 & & 0.005 & 5.500 & 1725 & & 0.005 & 1.880 \\
\hline
\end{tabular}

kidney $(y=-3.3274+0.022 * x)$ explains $81 \%$ of the data variability. The models for young bovine kidney $(\mathrm{y}=-4.8013+0.0025 * \mathrm{x})$ explain $40 \%$ of the data variability. Evaluation of trends for cow and young bovine muscle is presented in Fig. 2. The model for cow muscle $(y=0.687-0.0003 * x)$ accounts for $49 \%$ of the data variability. The models for young bovine muscle $(\mathrm{y}=0.8935-0.0004 * \mathrm{x})$ explain $89 \%$ of the data variability. The data point for cows and year 2007/2008 was considered as an outlier. Linear regression showed that mean concentrations of $\mathrm{Cd}$ in cow and young bovine liver are not dependent on time.

The distribution of total $\mathrm{Cd}$ dietary exposure doses were studied for the entire Czech population (aged 4-90) and specifically, for younger children (four to six years of age). Table 2 presents mean exposure doses of Cd estimated for the Czech population aged 4-90 and for four to six-year-old children and uncertainty bounds (2.5-97.5 percent) of exposure estimates. 


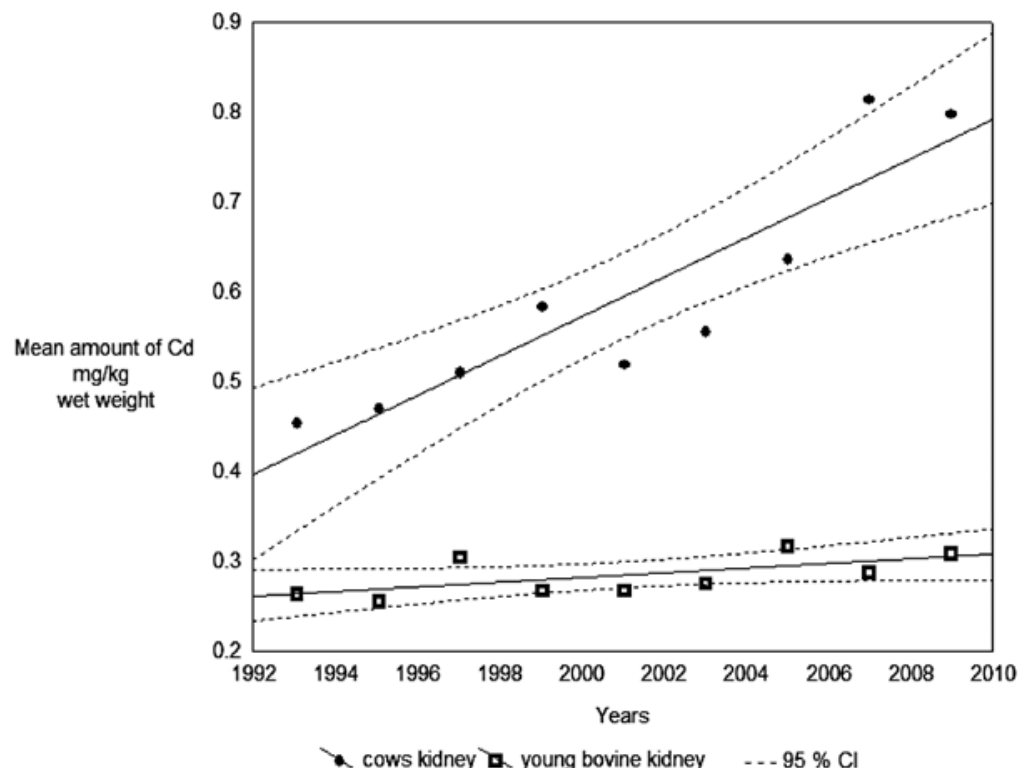

Fig. 1. Trends in the observed mean Cd concentrations in $\mathrm{mg} \cdot \mathrm{kg}^{-1}$ wet weight in cow and young bovine kidney during the time period of 1993-2010. The figure shows regression lines with $95 \%$ confidence interval (CI) of estimated models.

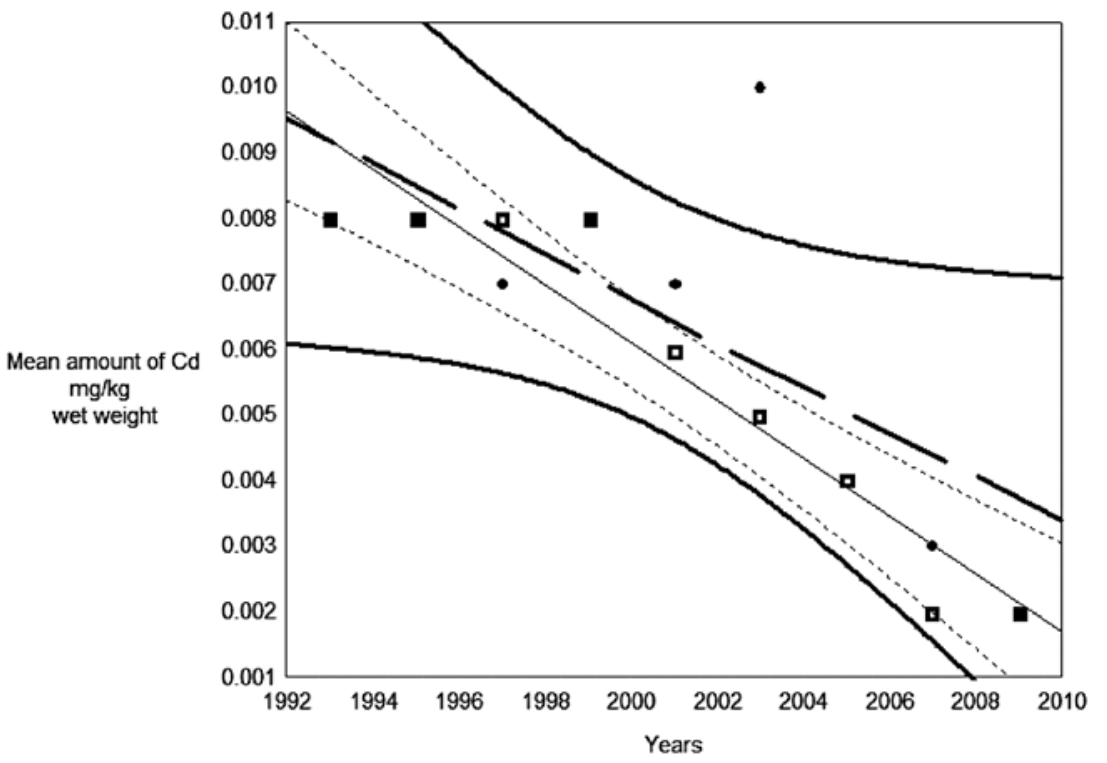

cows muscle $\mathbf{}$. young bovine muscle

$-95 \% \mathrm{Cl} \quad--95 \% \mathrm{Cl}$

Fig. 2. Trends in the observed mean Cd concentrations in $\mathrm{mg} \cdot \mathrm{kg}^{-1}$ wet weight in cow and young bovine muscle during the time period of 1993-2010. The figure shows regression lines with $95 \%$ confidence interval (CI) of estimated models. The point from year 2007/2008 in dataset for cows can be considered as an outlier. 
Table 2. Exposure doses of $\mathrm{Cd}$ estimated for the Czech population 4-90 years old and young children four to six years old, and uncertainty bounds (2.5-97.5 percent). TWI EFSA (2011) is $2.5 \mu \mathrm{g} \cdot \mathrm{kg}^{-1} \mathrm{of}$ body weight and week.

\begin{tabular}{lcccc}
\hline $\begin{array}{l}\text { Percentage } \\
\text { of population }\end{array}$ & $\begin{array}{c}\text { Exposure dose } \\
\text { (mg/kg b.w./week) }\end{array}$ & Lower bound (p2.5) & $\begin{array}{c}\text { Upper bound } \\
\text { (p97.5) dose }\end{array}$ & $\begin{array}{c}\text { Percentage of reference } \\
\text { (approx.) }\end{array}$ \\
$\begin{array}{l}\text { Population 4-90 years } \\
50\end{array}$ & 1.40 & 1.32 & 1.48 & 60 \\
90 & 2.49 & 2.35 & 2.64 & 100 \\
95 & 2.96 & 2.76 & 3.13 & 120 \\
99 & 3.98 & 3.72 & 4.25 & 160 \\
Young children 4-6 years & & & & \\
50 & 3.06 & 2.79 & 3.27 & 120 \\
90 & 4.29 & 3.83 & 4.76 & 170 \\
95 & 4.74 & 4.14 & 5.35 & 190 \\
99 & 5.63 & 4.79 & 6.48 & 230 \\
\hline
\end{tabular}

\section{Discussion}

The results included in Table 1 and Figs 1 and 2 support the hypothesis that arithmetic means of $\mathrm{Cd}$ concentration in muscle and kidney of both groups of bovine animals were changing during the studied period of time. It was not proven that the $\mathrm{Cd}$ content in cow and young bovine liver had changed in time. The mean concentration of $\mathrm{Cd}$ in cow kidney $\left(0.595 \mathrm{mg} \cdot \mathrm{kg}^{-1}\right)$ was twice as high as the mean concentration of $\mathrm{Cd}$ in young bovine kidney $\left(0.285 \mathrm{mg} \cdot \mathrm{kg}^{-1}\right)$ for the entire studied period. This fact was already described and logically explained by the tendency of $\mathrm{Cd}$ to cumulate in the kidneys (Drápal et al. 2012). The increase in $\mathrm{Cd}$ concentration in cow kidney is most probably connected with the age of animals as documented e.g. by Pechová et al. (1998) who confirmed the highly significant relation between the age of cows and $\mathrm{Cd}$ content in kidney. Unfortunately, data describing the mean age of cows slaughtered in the Czech Republic are not fully available for the entire examined period, but it is apparent that it was growing with time up to about 72 months. The decrease of concentrations that was observed in muscle tissue for both groups of bovine animals can also be related to methodological improvements and primary reporting left censored data $(<\mathrm{LOQ})$ from laboratories over the entire time period. The average concentration of $\mathrm{Cd}$ in cow muscle $\left(0.008 \mathrm{mg} \cdot \mathrm{kg}^{-1}\right)$ was comparable with young bovine muscle $\left(0.006 \mathrm{mg} \cdot \mathrm{kg}^{-1}\right)$. The average concentration of $\mathrm{Cd}$ in cow liver $\left(0.113 \mathrm{mg} \cdot \mathrm{kg}^{-1}\right)$ was higher in comparison with young bovine liver $\left(0.078 \mathrm{mg} \cdot \mathrm{kg}^{-1}\right)$. Similar results were reported by Doganoc (1996) who examined Cd concentrations in several hundreds of bovine animals for slaughter and detected the following values: $0.004 \mathrm{mg} \cdot \mathrm{kg}^{-1}$ meat, $0.094 \mathrm{mg} \cdot \mathrm{kg}^{-1}$ liver, and $0.350 \mathrm{mg} \cdot \mathrm{kg}^{-1}$ kidney. Niemi et al. (1991) detected the following Cd content: $0.001 \mathrm{mg} \cdot \mathrm{kg}^{-1}$ meat, $0.061 \mathrm{mg} \cdot \mathrm{kg}^{-1}$ liver, and $0.350 \mathrm{mg} \cdot \mathrm{kg}^{-1} \mathrm{kidney}$.

The experimental question posed was what these findings meant for food consumers. The long-term dietary exposure monitoring program for the Czech population (Total Diet Study) regularly describes the most important exposure sources of Cd (Ruprich 2014). The three most important sources of common exposure of the population aged between 4-90 years are (1) grains and grain-based products (39\%), (2) starchy roots and tubers $(16 \%)$, and (3) vegetables and vegetable products $(16 \%)$. The contribution of meat and meat products (including offal) is only about $6 \%$. While the estimated burden of the entire population is worthy of attention ( $10 \%$ is over the TWI EFSA), for younger children of 
four to six years of age this burden is even more critical. More than $50 \%$ of children are exposed to doses equal to TWI, 5\% of children are exposed to doses at 190\% TWI EFSA. The three most significant sources of usual exposure of children are (1) grains and grainbased products $(38 \%),(2)$ vegetables and vegetable products $(14 \%)$, and (3) starchy roots and tubers $(14 \%)$. The contribution of meat and meat products (including offal) is only about $4 \%$, while e.g. milk and dairy products could potentially represent more than $8 \%$ of usual exposure. This analysis confirmed the assumption that although the $\mathrm{Cd}$ concentration in some cattle tissues is growing up, total usual exposure from these tissues is still relatively low. However, due to emerging total exposure doses, the food safety recommendation is not to use cow kidney as food, especially for younger children. Even as small a portion as $70 \mathrm{~g}$ of cow kidney consumed within one week, with about $0.8 \mathrm{mg} \mathrm{Cd} \cdot \mathrm{kg}^{-1}$, can pose a certain health risk.

\section{Acknowledgments}

The authors would like to thank to the Czech State Veterinary Administration and the National Institute of Public Health in Prague, Centre for Health, Nutrition and Food in Brno for their kind consent with the use of official data sources. The project was also supported by Ministry of Health of the Czech Republic - DRO (National Institute of Public Health, IN -75010330).

\section{References}

Commission Decision 97/747/EC of 27 October 1997 fixing the levels and frequencies of sampling provided for by Council Directive 96/23/EC for the monitoring of certain substances and residues thereof in certain animal products. OJ L 303, 06/11/1997: 12-15

Commission Regulation (EC) No 1881/2006 of 19 December 2006 setting maximum levels for certain contaminants in foodstuffs. OJ L 364, 20/12/2006: 5-24

Council Directive 96/23/EC of 29 April 1996 on measures to monitor certain substances and residues thereof in live animals and animal products and repealing Directives 85/358/EEC and 86/469/EEC and Decisions 89/187/ EEC and 91/664/EEC. OJ L 125, 23/05/1996: 10-32

Dallongewille J, Marecaux N, Frauchart JCH, Anouyel P 1998: Cigarette smoking is associated with unhealthy patterns of nutrient intake: a meta-analysis. J Nutr 128: 1450-1457

Doganoc DZ 1996: Lead and cadmium concentrations in meat, liver and kidney of Slovenian cattle and pigs from 1989 to 1993. Food Addit Contam 13: 237-241

Drápal J, Hedbávný P, Střechová V, Št’astný K 2012: Bovine meat and offal as a source of human exposure to cadmium in the Czech Republic. Maso International 1: 55-61

EFSA (European Food Safety Authority) 2009: Scientific opinion of the panel on contaminants in the food chain on a request from the European Commission on cadmium in food. EFSA Journal 980: 1-139

EFSA (European Food Safety Authority) 2010: Standard sample description for food and feed. EFSA Journal 8:1457 [54 pp.] Available at: www.efsa.europa.eu/en/datexdata/docs/StandardSampleDescription.xls. Last modified April 20, 2014. Accessed February 5, 2015

EFSA (European Food Safety Authority) 2011: Panel on contaminants in the food chain (CONTAM): Scientific opinion on tolerable weekly intake for cadmium; EFSA Journal 9:1975[19pp], doi:10.2903/j.efsa.2011.1975. Available at: http://www.efsa.europa.eu/en/search/doc/1975.pdf. Last modified September 9, 2011. Accessed January 15,2015

IARC (International Agency for Research on Cancer) 2015: Monographs on the Evaluation of Carcinogenic Risk to Humans: Agents Classified by the IARC Monographs, Volumes 1-111. Available at:http://monographs.iarc. fr/ENG/Classification/ClassificationsGroupOrder.pdf. Last modified January 23, 2015. Accessed February 10, 2015

Kjellström T, Nordberg GF 1978: A kinetic model of cadmium metabolism in the human being. Environ Res 16: 248-269

Niemi A, Venalainen ER, Hirvi T, Hirn J, Karppanen E 1991: The lead, cadmium and mercury concentrations in muscle, liver and kidney from Finnish pigs and cattle during 1987-1988. Z Lebensm Unters Forsch 192: 427-429

Pechová A, Illek J, Pavlata L, Šindelář M, Horký D 1998: A comparison of cadmium concentrations in tissues of different categories of cattle. Acta Vet Brno 67: 103-107

Perkin-Elmer 1991: Graphite furnace AAS a source book. The Perkin-Elmer Corporation, Norwalk, 230 p.

Perkin-Elmer 1999: The THGA Graphite Furnace - Techniques and Recommended Conditions. The PerkinElmer Corporation, Norwalk, $62 \mathrm{p}$. 
Ruprich J 2014: Health effects and risks of human dietary exposure: exposure to chemical contaminants ("Total Diet Study" - 2012/2013), and the presence of GMOs in the food market in the Czech Republic: Cadmium. Expert report for 2013 (in Czech), NIPH. Available at:

http://czvp.szu.cz/monitor/tds13c/73\%20Kadmium.pdf. Last modified December 5, 2014. Accessed February 10,2015

Ruprich J, Dofková M, Řehůřková I, Slaměníková E, Resová D 2006: Individual food consumption - the national study SISP04. CHFCH NIPH in Prague. Available at: http://czvp.szu.cz/spotrebapotravin.htm. Last modified January19, 2012. Accessed February 5, 2015

Varian 1985: Varian Instruments at Work. Varian, Inc., Publ. No AA-52, Palo Alto, 52 p.

Varian 1988: Analytical Methods for Graphite Tube Atomizers. Varian, Inc., Publ. No. 85-100848-00, Palo Alto, $30 \mathrm{p}$.

Varian 2004: Varian ICP MS at Work. Varian, Inc., Publ. No: 023 and 024, Palo Alto, 66 p. 